\title{
SODIUM-AFFECTED ALFISOLS OF THE AGRESTE REGION, STATE OF PARAÍBA, BRAZIL, AS KNOWN BY POTTER-FARMERS AND AGRONOMISTS
}

\author{
Ângelo Giuseppe Chaves Alves*; Ivandro de França da Silva²; Sandra Barreto de Queiroz²; \\ Mateus Rosas Ribeiro ${ }^{3}$ \\ ${ }^{1}$ UFRPE - Depto. de Biologia, R. Manoel de Medeiros, s/n - Dois Irmãos - 52171-900 - Recife, PE - Brasil. \\ ${ }_{3}^{2} U F P B / C C A$ - Campus Universitário II - 58397-000 - Areia, PB - Brasil. \\ ${ }^{3}$ UFRPE - Depto. de Agronomia. \\ *Corresponding author <agcalves@db.ufrpe.br>
}

\begin{abstract}
Decisions and practical attitudes of land use and management adopted by rural populations are, to a great extent, based on local soil knowledge. This study was performed to describe and analyze chemical, physical and morphological characteristics of sodium-affected Alfisols employed in traditional pottery; and to compare, through statistical analysis, pedogenetical horizons and soil layers, as recognized in soil profiles by professional researchers and potterfarmers, respectively. Fieldwork was performed in Chã da Pia, a rural village in the municipality of Areia, in the Agreste region of the State of Paraíba, Northeast Brazil. Ethnoscientific techniques were used to describe and analyze soil knowledge of potter-farmers who played the role of informants. A comparison of soil categories recognized by farmers and researchers was performed through discriminant-canonical analysis. Soils from which local people obtain a material named "barro de loiça" (pottery clay) were classified as Typic Natraqualf and Vertic Albaqualf, according to Soil Taxonomy. Potter-farmers were able to identify differences between the tillable topsoil and underlying layers from which they extract ceramic clay. Some soil layers, recognized by potterfarmers, were similar to pedogenetic horizons of the same soils, recognized by researchers, in terms of physical, chemical and morphological characteristics. Discriminant-canonical analysis was a useful tool to articulate and compare information related to soil knowledge held by distinct social groups.
\end{abstract}

Key words: ethnopedology, discriminant-canonical analysis, pottery, local knowledge

\section{PLANOSSOLOS AFETADOS POR SÓDIO NO AGRESTE PARAIBANO CONFORME CONHECIDOS POR AGRICULTORES-CERAMISTASE AGRÔNOMOS}

\begin{abstract}
RESUMO: As decisões e ações de uso e manejo adotadas pelas populações rurais são, em grande parte, baseadas no conhecimento pedológico local. Este trabalho teve como objetivos descrever e analisar as características químicas, físicas e morfológicas de Planossolos afetados por sódio usados em cerâmica artesanal e estabelecer, por meio de análise multivariada, comparações entre os horizontes pedogenéticos e as camadas reconhecidas nos perfil de solo por agricultores-ceramistas. O trabalho de campo foi realizado em Chã da Pia, localidade rural no município de Areia, Agreste Paraibano. Técnicas etnocientíficas foram empregadas para descrever e analisar os conhecimentos pedológicos dos agricultores-ceramistas que atuaram como informantes. A comparação entre as categorias de solos reconhecidos por agricultores e pesquisadores foi realizada por meio de análise discriminante-canônica. Os solos de onde se extrai o material localmente denominado "barro de loiça”, dentro do contexto estudado, foram classificados como Planossolo Nátrico e Planossolo Háplico no Sistema Brasileiro de Classificação de Solos. Nesses solos, os agricultores-ceramistas foram capazes de identificar diferenças entre as partes superiores do perfil, associadas à camada arável e aquelas mais profundas, que servem como fonte de material cerâmico. Demonstrou-se também similaridade física, química e morfológica entre algumas camadas dos perfis de solo, reconhecidas por agricultores-ceramistas e determinados horizontes pedogenéticos dos mesmos solos. A análise discriminante-canônica foi útil para articulação e comparação de informações oriundas de conhecimentos pedológicos diversos.

Palavras-chave: etnopedologia, análise discriminante canônica, cerâmica, conhecimento local
\end{abstract}




\section{INTRODUCTION}

The need of fitting land use strategies to local reality has determined the quest for efficient mechanisms for communication among researchers with formal education and rural populations, mainly small scale farmers. Ethnopedological studies attempt to support this pursue since they may provide more in-depth understanding of the relationship among humans, soils and other constituents of the ecosystems (Alves \& Marques, 2005; Alves et al., 2006). The rationale is that social groups tend to assign different meanings to soils (Brady, 1989; Krasilnikov \& Tabor, 2003; Cooper et al., 2005), and that decisions and practical attitudes of use and management adopted by these groups are based on their specific knowledge and cosmovision. These are generally transmitted through generations without necessarily using written language (Toledo, 2000).

Statistical multivariate analysis has shown to be useful in pedological studies, facilitating the comparison and integration between soil data sets, even when they are related to different social groups (e.g. soil scientists and peasants), as it happens in ethnopedological research (Williams \& Ortiz-Solorio, 1981; Queiroz \& Norton, 1992). In this study, “formal" soil knowledge is that one which is shared by researchers with academic education (soil scientists, in this case), while the knowledge shared by social groups which use and manage soil resources in their daily activities (peasant potters, in this case) is assumed to be "local" (1).

The majority of ethnopedological studies have focused local knowledge on the tillable topsoil, with special emphasis on the spatial distribution of soil categories over the land surface as recognized by the populations under study. On the other hand, BarreraBassols \& Zinck (2003) have shown the existence and importance of peasant knowledge of soil variations with depth. In the Agreste region of the Paraíba State (Brazil), Alves et al. (2005) observed that some potterfarmers recognized differences between tillable topsoil and underlying soil in Albaqualfs and Natraqualfs, and were also capable of distinguishing, identifying and naming, on their own language and criteria, some of the soil materials stratified throughout the profile.

This study had the objective of describing and analyzing chemical, physical and morphological features of some soils used in traditional pottery and to establish, through statistical multivariate analysis, com- parisons between pedogenetical horizons and the layers recognized in sodium-affected Alfisols by local potter-farmers in Areia, State of Paraíba, Brazil.

\section{MATERIAL AND METHODS}

\section{Data Collection and Analysis}

Fieldwork was performed in Chã da Pia, which is located in the rural zone of the municipality of Areia (Agreste region of Paraíba State), Brazil. Approximately forty people were working directly and regularly in the making of pottery clay ("loiça de barro") for commerce and family usage in the area, and they call themselves "loiceiros" (potters) ${ }^{(2)}$. Local altitude varies between 484 and $552 \mathrm{~m}$, latitude between 6 ${ }^{\circ} 54^{\prime} 15^{\prime \prime}$ ' and 6 $6^{\circ} 55^{\prime} 6^{\prime \prime} \mathrm{S}$, and longitude between $35^{\circ} 46^{\prime} 39^{\prime \prime}$ and $35^{\circ} 47^{\prime} 41^{\prime \prime}$ W. Predominant relief is undulated or gently undulated. The climate is As' (hot and dry, with rain during autumn and winter), according to the Köppen's classification, with annual rainfall averaging $700 \mathrm{~mm}$ (Jacomine et al., 1972).

During the first phase of the fieldwork, 35 local potter-farmers worked as informants through openended interviews (Albuquerque \& Lucena, 2004). Afterwards the interviews were intercalated with tours (Spradley, 1979) in which potter-farmers guided the authors to the sources of "barro de loiça" (local denomination of the soil materials that provide plasticity to the ceramic paste). The information obtained was recorded in tape and registered on field notebooks for later transcription, systematization and analysis. In addition to the information offered by the peasant craftsmen, the authors obtained data related to soils used in local pottery through direct observation. Sampling and soils description were performed through conventional methods (Santos et al., 2005) in five sites (pottery clay sources) by four agronomists (the authors of this paper) who had previously accomplished graduate studies in soil science, thus with formal knowledge in Pedology.

For each of the five profiles, following conventional description, complementary soil sampling was done with the help of an informant who was asked to name and describe, according to local knowledge, the soils (or soil materials) of the location. Pointing to the soil profile, the authors would ask questions such as: "show me where the pottery clay is" and "what else can you show me here?"

\footnotetext{
(1)Santos (2006) has shown that some local features may be found in formal or scientific knowledge. So, the adjectives "formal" and "local", as used in this paper, do not mean the opposite of each other.

${ }^{(2)}$ The term "loiça” is widely used in colloquial language in Northeast Brazil, and refers to traditional pottery. It appears in the "Aurélio" Dictionary [http://www.uol.com.br/Aurelio] as being parallel to “louça”. Access in June, 2004.
} 
The materials indicated by the potter-farmers were collected and sent for laboratory analysis, as well the samples from the previous conventional soil profile description. The methods described by Embrapa (1997) were used in the laboratory analyses. An attempt at establishing comparisons and articulations between the results of the two soil sampling approaches (with and without the presence of potter-farmers) was made, after the fieldwork and laboratorial results were obtained. Other information on the studied environment and the procedures for soil collection and analysis are available in Alves (2004) and Alves et al. (2005).

\section{Multivariate Statistical Analysis}

Considering that informants used to know and manage different soil material categories, which seemed to be arranged as strata on the soil profiles (Alves, 2004; Alves et al., 2005), it was hypothesized that it would be possible to compare peasant soil material categories, locally named "capas” (from here on, simply "layers"), with the pedogenetic horizons of the same soils, through multivariate statistical analysis. This hypothesis was tested through discriminant-canonical analysis (DCA), based on some of the morphological, physical and chemical features of the soils. In this case, laboratorial (physical and chemical) and field (morphological) analysis results were used for both data sets: the layers and horizons.

Previous studies where multivariate analysis was applied to pedological and ethnopedological data treated the "individuals" as soil profiles (Cipra et al., 1970; Queiroz \& Norton, 1992; Vaselli et al., 1997), topsoil layers (Williams \& Ortiz-Solorio, 1981) or treatments applied on soils such as farming systems (Quiroga et al., 1998; Silva et al., 2001), among others. However, in this particular case, the "individuals" analyzed and compared were sections (horizons and layers) found in the profiles of some soils (Alfisols) that have been used for multi-crop farming and earthenware production. In this study, a direct comparison among soil profile sections recognized by farmers and researchers was made. An advantage of this approach was the possibility of demonstrating whether (and how) farmers recognized soil variation in depth.

For statistical purposes, the nine categories previously defined were: horizons $A(n=7)$, E $(n=5), B t(n=9)$ and BC ( $=4)$; and layers, locally named "terra" (earth, $n=5$ ), "piçarro" (gravelly bleached soil, $\mathrm{n}=3$ ), "cabeça do barro" (clay head, $\mathrm{n}=4$ ), "barro de loiça" (pottery clay, $\mathrm{n}=5$ ), and "pedra mole" (soft rock, $n=5$ ). Then, a total of 47 individuals were analyzed, including 22 samples of layers and 25 samples of horizons.
Part of the chemical, physical and morphological data used in the statistical analysis (those from potter-farmers' layers) were published in Alves et al. (2005), whilst this paper brings a different data set that represents the pedogenetic horizons of the same soils.

Linear functions (canonical roots) were estimated through DCA, based on selected independent variables data, enabling the distinction and listing of individuals, maximizing variance among the groups and minimizing variance within the groups (Silva et al., 2001). The program "Statistica” (Statsoft, 1995) was used to perform the analysis. Based on a combination of data from original variables, DCA makes it possible to obtain compound variables named canonical roots or discriminating functions. Each canonical root consists of a linear combination (Z) of the independent variables (Yi), in order to maximize the correlation between $\mathrm{Z}$ and Yi. The linear combination of i variables $\mathrm{Y}$, forming a discriminant function $\mathrm{Z}$ may be represented by the following model: $\mathrm{Z}=\mu_{0}+\mu_{1} \mathrm{Y}_{1}+\mu_{2} \mathrm{Y}_{2}+\mu_{3} \mathrm{Y}_{3}+\ldots+\mu_{\mathrm{i}} \mathrm{Y}_{\mathrm{i}}$. In this model, $\mu_{1}, \mu_{2} \ldots \mu_{i}$ are canonical coefficients estimated for the data, whilst $\mathrm{Y}_{1}, \mathrm{Y}_{2} \ldots \mathrm{Y}_{\mathrm{i}}$ are the values of independent variables.

In this study, a discriminant model was built step by step using a "forward stepwise" analytical procedure. In each step, all variables were reevaluated and those that would contribute the most to discriminate among the groups were detected. This variable was then included in the model and the procedure continued with the other variables, included one by one, until completion. During this procedure, the variables that did not significantly contribute to group distinction were excluded (Statsoft, 1995).

A total of twenty-eight independent variables were inserted in the analysis, six of them related to morphological features, 11 to physical features and the other 11 to chemical features of layers and horizons. Variables with a high potential degree of intercorrelation with others were excluded. Thus, values of silt and clay were inserted, but the relation silt/clay was excluded, despite being used as a criterion to classify specific soils. In the same way, exchangeable cation values were inserted, but the sum of basic cations was excluded, otherwise it would not be possible to perform the test. The problem of "constant sum" that occurs, for example, with the sum of granulometric fractions, was considered as well. In this case, one of the fractions (coarse sand) was excluded, as performed by Vaselli et al. (1997).

Qualitative data from morphological variables were codified into numeric values (Table 1), similar to those described by Queiroz (1985) and Queiroz \& Norton (1992). Hue was codified from 1 (redder) to 
Table 1 - Morphological soil attributes and codes used in the discriminant canonical analysis, based on Queiroz (1985) and Queiroz \& Norton (1992).

\begin{tabular}{|c|c|c|c|c|c|c|c|c|c|c|c|}
\hline \multicolumn{2}{|c|}{ Hue } & \multicolumn{2}{|c|}{ Chroma } & \multicolumn{2}{|c|}{ Value } & \multicolumn{2}{|l|}{ Texture } & \multicolumn{2}{|c|}{ Plasticity } & \multicolumn{2}{|c|}{ Stickiness } \\
\hline Class & Code & Class & Code & Class & Code & Class & Code & Class & Code & Class & Code \\
\hline $10 \mathrm{R}$ & 1 & 1 & 1 & 2 & 2 & Sand & 1 & Non plastic & 1 & Non sticky & 1 \\
\hline $2.5 \mathrm{YR}$ & 2 & 2 & 2 & 2.5 & 2.5 & $\begin{array}{l}\text { Loamy sandy, silt, } \\
\text { Sandy loam }\end{array}$ & 2 & Slightly plastic & 2 & Slightly sticky & 2 \\
\hline $5 \mathrm{YR}$ & 3 & 3 & 3 & 3 & 3 & Clay loam, loam & 3 & Plastic & 3 & Sticky & 3 \\
\hline $7.5 \mathrm{YR}$ & 4 & 4 & 4 & 4 & 4 & $\begin{array}{l}\text { Sandy clay loam, silty } \\
\text { clay loam, clay loam }\end{array}$ & 4 & Very plastic & 4 & Very sticky & 4 \\
\hline $10 \mathrm{YR}$ & 5 & 6 & 6 & 5 & 5 & $\begin{array}{l}\text { Silty clay, sandy clay, } \\
\text { clay }\end{array}$ & 5 & --- & --- & --- & --- \\
\hline $2.5 \mathrm{Y}$ & 6 & 8 & 8 & 6 & 6 & Very clayey $(*)$ & 6 & --- & --- & --- & --- \\
\hline $5 \mathrm{Y}$ & 7 & & & 7 & 7 & Vertic & 7 & --- & --- & --- & --- \\
\hline $10 \mathrm{Y}$ & 8 & & & 8 & 8 & --- & --- & -- & --- & --- & -- \\
\hline
\end{tabular}

*Clay content higher than $60 \mathrm{~g} \mathrm{~kg}^{-1}$. This class is admitted in Brazil (Santos et al., 2005), but not in Soil Taxonomy (Soil Survey Staff, 1999).

8 (more yellow); chroma was codified from 1 (lower intensity of hue) to 8 (higher intensity of hue); value was codified from 2 (higher contribution of black) to 8 (higher contribution of white); texture was codified from 1 (higher influence of the sand fraction) to 7 (higher influence of clay and/or expansive mineral fractions); plasticity and stickiness were both codified from 1 (non plastic, non sticky) to 4 (very plastic and very sticky). For statistical purposes, the color of the wet samples was considered, while formal classification was based on the color of moist and dry samples. After thoroughly mixed with water, the samples presented uniform color, while the moist soil sometimes had a variegated color pattern. Having a single color for each (wet) sample made it possible to consider color aspects (hue, chroma and value) as variables in the statistical procedure.

\section{RESULTS AND DISCUSSION}

Soils described in places where pottery clay was normally extracted by local potters were classified as Typic Natraqualf e Vertic Albaqualf (Soil Survey Staff, 1999), which correspond to Planossolo Nátrico e Planossolo Háplico in the Brazilian Soil Classification System (Embrapa, 2006), respectively (Tables 2 to 4).

Pottery clay was normally extracted from $\mathrm{Bt}$ horizons (Alves, 2004; Alves et al., 2005). These horizons generally present a clayey texture. Dry samples were extremely hard and extremely firm, while wet samples ranged from sticky to very sticky and, from plastic to very plastic (Tables 2 to 4). Brownish colors were predominant with the exception of profile 3 (with vertic properties), where grayish colors were prevalent. From a chemical viewpoint the hyper- eutrophic feature was remarkable, as well as the relatively high sodium saturation levels in the exchange sites (from 7 to $25 \%$ ).

Local slope ranged between $4 \%$ ( $3^{\text {rd }}$ profile) and $24 \%$ ( $5^{\text {th }}$ profile). Natraqualfs and Albaqualfs are most commonly associated to plain and gently undulated relief, but may occur in sites with relatively high slope in the Brazilian Northeast (Sampaio et al., 1976) and in other regions (Faivre, 1977). Sodium-affected Argids locally named "barro de louça" (pottery clay, in reference to the Bt horizon) occur in the Acaraú River Valley (Ceará State), under a large slope range, not being restricted only to low slope sites near streams and rivers (Queiroz, 1985).

\section{Discriminant-Canonical Analysis}

The canonical roots analysis contributed to distinguish local and formal categories (layers and horizons, respectively) related to the soils under study (Wilk's lambda $=0.00001$ and $P<0.0001$ ) (Table 5). In this case, lower partial lambda values indicated higher contribution of the respective variables for group distinction. Therefore, the variable contributing the most was depth, followed by extractable phosphorus, $\mathrm{pH}$ in $1 \mathrm{~mol} \mathrm{~L}^{-1} \mathrm{KC} 1$, chroma, gravel content and electrolytic conductivity. Because depth was the most discriminating variable, it ratified a trend going back to the beginning of the $20^{\text {th }}$ century, when soil horizons were identified mainly by their relative position in the profile (Nikiforoff, 1931).

Judging by the distance between centroids (Table 6) there were similarities between certain local and formal soil categories, as follows: "terra" was particularly similar to the A horizons and, to a lesser degree, to E horizons. On the other hand, "piçarro" was particularly similar to E horizons and, to a lesser de- 
Table 2 - Morphological attributes of soils that are used as a source of pottery clay by peasant potters in Chã da Pia, Paraíba, Brazil.

\begin{tabular}{|c|c|c|c|c|c|c|}
\hline Hor. ${ }^{1}$ & Depth (cm) & Color $^{2}$ & Texture & Structure & Consistence & Boundary \\
\hline \multicolumn{7}{|c|}{ Profile 1: Typic Natraqualf } \\
\hline Ap & $0-26$ & Dark brown $(7.5 \mathrm{YR} 3 / 3 \mathrm{~m}, \mathrm{w})$ & Loamy sandy & $\begin{array}{l}\text { massive aspect,breaking to weak coarse } \\
\text { angular blocky }\end{array}$ & $\begin{array}{l}\text { Slightly hard, very friable, } \\
\text { non sticky and non plastic }\end{array}$ & Wavy clear $(23-30 \mathrm{~cm})$ \\
\hline E & $26-33$ & Brown (7.5YR 4/3 m, w) & Loamy sandy & --- & $\begin{array}{l}\text { very hard, very friable, non } \\
\text { sticky and non plastic }\end{array}$ & Smooth abrupt \\
\hline $2 \mathrm{Btn}$ & $33-51$ & $\begin{array}{l}\text { Dark brown }(7.5 \mathrm{YR} 3 / 2 \mathrm{~m}, \mathrm{w}) \text {; many medium } \\
\text { prominent dark red mottles }(2.5 \text { YR } 3 / 6 \mathrm{~m})\end{array}$ & Clay & $\begin{array}{l}\text { strong coarse prismatic mixed with } \\
\text { strong coarse angular blocky }\end{array}$ & $\begin{array}{l}\text { Extremely hard, extremely } \\
\text { firm, sticky and very plastic }\end{array}$ & Wavy abrupt $(13-25 \mathrm{~cm})$ \\
\hline $2 \mathrm{BCn}$ & $51-73$ & $\begin{array}{l}\text { Brown }(10 \text { YR } 4 / 3 \mathrm{~m}) \text {, olive brown }(2.5 \mathrm{Y} 4 / 3 \mathrm{w}) \text {; } \\
\text { many coarse distinct strong brown mottles, with a } \\
\text { micaceous aspect }(7.5 \mathrm{YR} 5 / 6 \mathrm{~m})\end{array}$ & $\begin{array}{l}\text { Micaceous sandy } \\
\text { clay }\end{array}$ & strong medium prismatic & $\begin{array}{l}\text { Extremely hard, extremely } \\
\text { firm, sticky and plastic; }\end{array}$ & Wavy clear $(17-33 \mathrm{~cm})$ \\
\hline $2 \mathrm{Cr}$ & $73-90+$ & 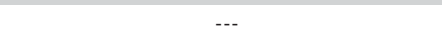 & -- & --- & --- & --- \\
\hline \multicolumn{7}{|c|}{ Profile 2: Typic Natraqualf } \\
\hline Ap & $0-35$ & Dark brown ( 7.5 YR $3 / 3 \mathrm{~m} ; 7.5$ YR $3 / 2 \mathrm{w})$ & Sandy loam & $\begin{array}{l}\text { massive aspect, breaking to weak } \\
\text { coarse angular and subangular blocky } \\
\text { and coarse prismatic }\end{array}$ & $\begin{array}{l}\text { slightly hard, very friable, non } \\
\text { sticky and non plastic }\end{array}$ & Smooth clear \\
\hline E & $35-51$ & Brown (10YR 4/3 m, w). & Loamy sandy & $\begin{array}{l}\text { massive aspect, breaking to weak } \\
\text { medium and coarse prismatic }\end{array}$ & $\begin{array}{l}\text { slightly hard, very friable, non } \\
\text { sticky and non plastic }\end{array}$ & Smooth abrupt \\
\hline $2 \mathrm{Btn}{ }_{1}$ & $51-62$ & $\begin{array}{l}\text { Brown (10YR } 4 / 3 \mathrm{~m}, \mathrm{w}) \text {; common medium } \\
\text { prominent red mottles }(10 \mathrm{R} 4 / 8 \mathrm{~m})\end{array}$ & Clay & strong coarse prismatic & $\begin{array}{l}\text { Extremely hard, extremely } \\
\text { firm, very sticky and very } \\
\text { plastic }\end{array}$ & Wavy abrupt $(06-13 \mathrm{~cm})$ \\
\hline $2 \mathrm{Btn}{ }_{2}$ & $62-80$ & $\begin{array}{l}\text { Variegated: brown }(10 \mathrm{YR} 5 / 3 \mathrm{~m}) \text {, grayish brown } \\
(10 \mathrm{YR} 5 / 2 \mathrm{~m}) \text {, dark grayish brown }(10 \mathrm{YR} 4 / 2 \mathrm{~m}) \text {, } \\
\text { very dark gray }(10 \mathrm{YR} 3 / 1 \mathrm{~m}) \text { and red }(10 \mathrm{R} 4 / 6 \\
\text { m); yellowish brown }(10 \mathrm{YR} 5 / 4 \mathrm{w})\end{array}$ & Sandy clay & strong medium and coarse prismatic & $\begin{array}{l}\text { Extremely hard, extremely } \\
\text { firm, sticky and plastic }\end{array}$ & Wavy abrupt $(8-18 \mathrm{~cm})$ \\
\hline $2 \mathrm{BCn}$ & $80-85$ & $\begin{array}{l}\text { Variegated: very dark gray }(10 \mathrm{YR} 3 / 1 \mathrm{~m}) \text {, brown } \\
(10 \mathrm{YR} 5 / 3 \mathrm{~m}) \text {, strong brown }(7.5 \mathrm{YR} 4 / 6 \mathrm{~m}) \text {, pale } \\
\text { brown }(10 \mathrm{YR} 6 / 3 \mathrm{~m}) \text { and brownish yellow }(10 \mathrm{YR} \\
6 / 6 \mathrm{~m}) \text {; yellowish brown }(10 \mathrm{YR} 5 / 4 \mathrm{w})\end{array}$ & Sandy clay & strong medium and coarse prismatic & $\begin{array}{l}\text { Extremely hard, extremely } \\
\text { firm, sticky and plastic }\end{array}$ & Wavy clear $(03-05 \mathrm{~cm})$ \\
\hline $2 \mathrm{Cr}$ & $85-95+$ & --- & --- & --- & --- & --- \\
\hline \multicolumn{7}{|c|}{ Profile 3: Vertic Albaqualf } \\
\hline Ap & $0-12$ & Very dark gray $(10 \mathrm{YR} 3 / 1 \mathrm{~m}, \mathrm{w})$. & Sandy loam & $\begin{array}{l}\text { Weak coarse angular and subangular } \\
\text { blocky and medium prismatic }\end{array}$ & $\begin{array}{l}\text { Extremely hard, friable, } \\
\text { slightly sticky and slightly } \\
\text { plastic }\end{array}$ & Smooth abrupt \\
\hline A & $12-20$ & Very dark gray $(10 \mathrm{YR} 3 / 1 \mathrm{~m}, \mathrm{w})$ & Sandy loam & $\begin{array}{l}\text { massive aspect, breaking to weak } \\
\text { coarse angular blocky }\end{array}$ & $\begin{array}{l}\text { Extremely hard, friable, } \\
\text { slightly sticky and slightly } \\
\text { plastic }\end{array}$ & Wavy abrupt $(3-8 \mathrm{~cm})$ \\
\hline $2 \mathrm{Btnv}_{1}$ & $20-42$ & Very dark gray (10YR $3 / 1 \mathrm{~m}, \mathrm{w})$ & Clay & strong coarse prismatic & $\begin{array}{l}\text { Extremely hard, extremely } \\
\text { firm, very sticky and plastic }\end{array}$ & Wavy clear $(13-25 \mathrm{~cm})$ \\
\hline $2 \mathrm{Btnv}_{2}$ & $42-71$ & Olive gray $(5 \mathrm{Y} 4 / 2 \mathrm{~m})$, dark gray ( $5 \mathrm{Y} 4 / 1 \mathrm{w})$ & Clay & strong coarse prismatic & $\begin{array}{l}\text { Extremely hard, very firm, } \\
\text { very sticky and very plastic }\end{array}$ & Wavy clear $(17-31 \mathrm{~cm})$ \\
\hline 2Crnz & $71-95$ & Olive gray $(5 Y 5 / 2 \mathrm{w})$ & Silty clay & $----\cdot$ & Slightly sticky and plastic & Smooth abrupt \\
\hline $2 \mathrm{R}$ & $95+$ & $--\cdot$ & $--\cdot$ & --- & $--\cdot$ & $--\cdot$ \\
\hline \multicolumn{7}{|c|}{ Profile 4: Typic Natraqualf } \\
\hline Ap & $0-5$ & Dark brown (10YR $3 / 3 \mathrm{~m}, \mathrm{w})$. & Sandy loam & Weak medium and coarse granular & $\begin{array}{l}\text { Slightly hard, very friable, } \\
\text { slightly sticky and slightly } \\
\text { plastic }\end{array}$ & Smooth abrupt \\
\hline E & $5-26$ & Dark brown (10YR $3 / 3$ m, w). & Sandy loam & $\begin{array}{l}\text { Massive aspect, weak very coarse } \\
\text { laminar }\end{array}$ & $\begin{array}{l}\text { Very hard, very friable, } \\
\text { slightly sticky and slightly } \\
\text { plastic }\end{array}$ & Smooth abrupt \\
\hline $2 \mathrm{Btn}_{1}$ & $26-38$ & $\begin{array}{l}\text { Dark yellowish brown }(10 \mathrm{YR} 4 / 4 \mathrm{~m}) \text {, brown } \\
(10 \mathrm{YR} 5 / 3 \mathrm{w}) \text {; many medium faint very dark } \\
\text { grayish brown mottles }(10 \mathrm{YR} 3 / 2 \mathrm{~m}) .\end{array}$ & Gravely clay & Strong coarse angular blocky & $\begin{array}{l}\text { Extremely hard, extremely } \\
\text { firm, very sticky and very } \\
\text { plastic }\end{array}$ & Smooth clear \\
\hline $2 \mathrm{Btn}_{2}$ & $38-52$ & $\begin{array}{l}\text { Dark yellowish brown (10YR } 4 / 4 \mathrm{~m}) \text {, yellowish } \\
\text { brown }(10 \mathrm{YR} 5 / 4 \mathrm{w}) \text {, common coarse distinct very } \\
\text { dark grayish brown mottles }(10 \mathrm{YR} 3 / 2 \mathrm{~m})\end{array}$ & Clay & Strong coarse angular blocky & $\begin{array}{l}\text { Extremely hard, extremely } \\
\text { firm, very sticky and very } \\
\text { plastic }\end{array}$ & Wavy clear $(14-27 \mathrm{~cm})$ \\
\hline 2BCnz & $52-105+$ & $\begin{array}{l}\text { Variegated: brown }(10 \mathrm{YR} 4 / 3 \mathrm{~m}) \text {, yellowish brown } \\
(10 \mathrm{YR} 5 / 6, \mathrm{~m}) \text { and very dark gray }(10 \mathrm{YR} 3 / 1 \mathrm{~m}) \\
\text { yellowish brown }(10 \mathrm{YR} 5 / 4 \mathrm{w}) .\end{array}$ & Clay & Weak medium prismatic & $\begin{array}{l}\text { Extremely hard, very friable, } \\
\text { sticky and very plastic }\end{array}$ & \\
\hline \multicolumn{7}{|c|}{ Profile 5: Typic Natraqualf } \\
\hline $\mathrm{Ap}_{1}$ & $0-5$ & $\begin{array}{l}\text { Very dark grayish brown (10YR } 3 / 2 \mathrm{~m}) \text {, dark } \\
\text { brown }(10 \mathrm{YR} 3 / 3 \mathrm{w}) .\end{array}$ & Loamy sandy & Weak coarse and very coarse granular & $\begin{array}{l}\text { Slightly hard, very friable, } \\
\text { non sticky and non plastic }\end{array}$ & Smooth clear \\
\hline $\mathrm{Ap}_{2}$ & $5-21$ & Dark brown (10YR $3 / 3 \mathrm{~m}$, w). & Sandy loam & $\begin{array}{l}\text { Massive breaking to weak medium } \\
\text { prismatic and coarse angular blocky }\end{array}$ & $\begin{array}{l}\text { Slightly hard, friable, non } \\
\text { sticky and non plastic }\end{array}$ & Smooth clear \\
\hline $\mathrm{E}_{1}$ & $21-38$ & $\begin{array}{l}\text { Yellowish brown (10YR } 5 / 4 \mathrm{~m} \text { ), brown (10YR } 5 / 3 \\
\text { w). }\end{array}$ & Loamy sandy & Single grained with some prismatic clods & $\begin{array}{l}\text { Loose, very friable, non } \\
\text { sticky and non plastic }\end{array}$ & Smooth clear \\
\hline $\mathrm{E}_{2}$ & $38-43$ & Brown (10YR 5/3 m, w). & Sandy loam & Massive breaking to blocky & $\begin{array}{l}\text { Extremely hard, friable, non } \\
\text { sticky and non plastic }\end{array}$ & Smooth abrupt \\
\hline $2 \mathrm{Btn}_{1}$ & $43-59$ & $\begin{array}{l}\text { Variegated: dark yellowish brown (10YR } 4 / 6 \mathrm{~m}) \text {, } \\
\text { and dark grayish brown }(10 \mathrm{YR} 4 / 2 \mathrm{~m}) \text {; dark } \\
\text { yellowish brown }(10 \mathrm{YR} 4 / 4 \mathrm{w}) .\end{array}$ & Clay & $\begin{array}{l}\text { Strong coarse prismatic and coarse } \\
\text { angular blocky }\end{array}$ & $\begin{array}{l}\text { Extremely hard, extremely } \\
\text { firm, very sticky and very } \\
\text { plastic }\end{array}$ & Wavy clear $(14-20 \mathrm{~cm})$ \\
\hline $2 \mathrm{Btn}_{2}$ & $59-81$ & $\begin{array}{l}\text { Dark yellowish brown }(10 \mathrm{YR} 4 / 6 \mathrm{~m}) \text {, yellowish } \\
\text { brown }(10 \mathrm{YR} 5 / 4 \mathrm{w}) \text {; few medium distinct dark } \\
\text { grayish brown mottles }(10 \mathrm{YR} 4 / 2 \mathrm{~m})\end{array}$ & Clay & $\begin{array}{l}\text { Strong medium and coarse prismatic and } \\
\text { coarse angular blocky }\end{array}$ & $\begin{array}{l}\text { Extremely hard, extremely } \\
\text { firm, very sticky and plastic }\end{array}$ & Wavy clear $(19-26 \mathrm{~cm})$ \\
\hline $2 \mathrm{BCn}$ & $81-92+$ & $\begin{array}{l}\text { Variegated: red }(10 \mathrm{R} 4 / 8 \mathrm{~m}) \text {, yellowish brown } \\
(10 \mathrm{YR} 5 / 8, \mathrm{~m}) \text { and brown }(7.5 \mathrm{YR} 4 / 2 \mathrm{~m}) ; \\
\text { yellowish brown }(10 \mathrm{YR} 5 / 4 \mathrm{w}) .\end{array}$ & Clay & $\begin{array}{l}\text { Partly massive, partly moderate coarse } \\
\text { blocky }\end{array}$ & $\begin{array}{l}\text { Extremely hard, extremely } \\
\text { firm, very sticky and very } \\
\text { plastic }\end{array}$ & \\
\hline
\end{tabular}

${ }^{1}$ Horizons; ${ }^{2}$ Samples used in soil color determination: $\mathrm{m}=$ moist; $\mathrm{w}=$ wet. 
Table 3 - Physical attributes of soils that are used as a source of pottery clay by peasant potters in Chã da Pia, Paraíba, Brazil.

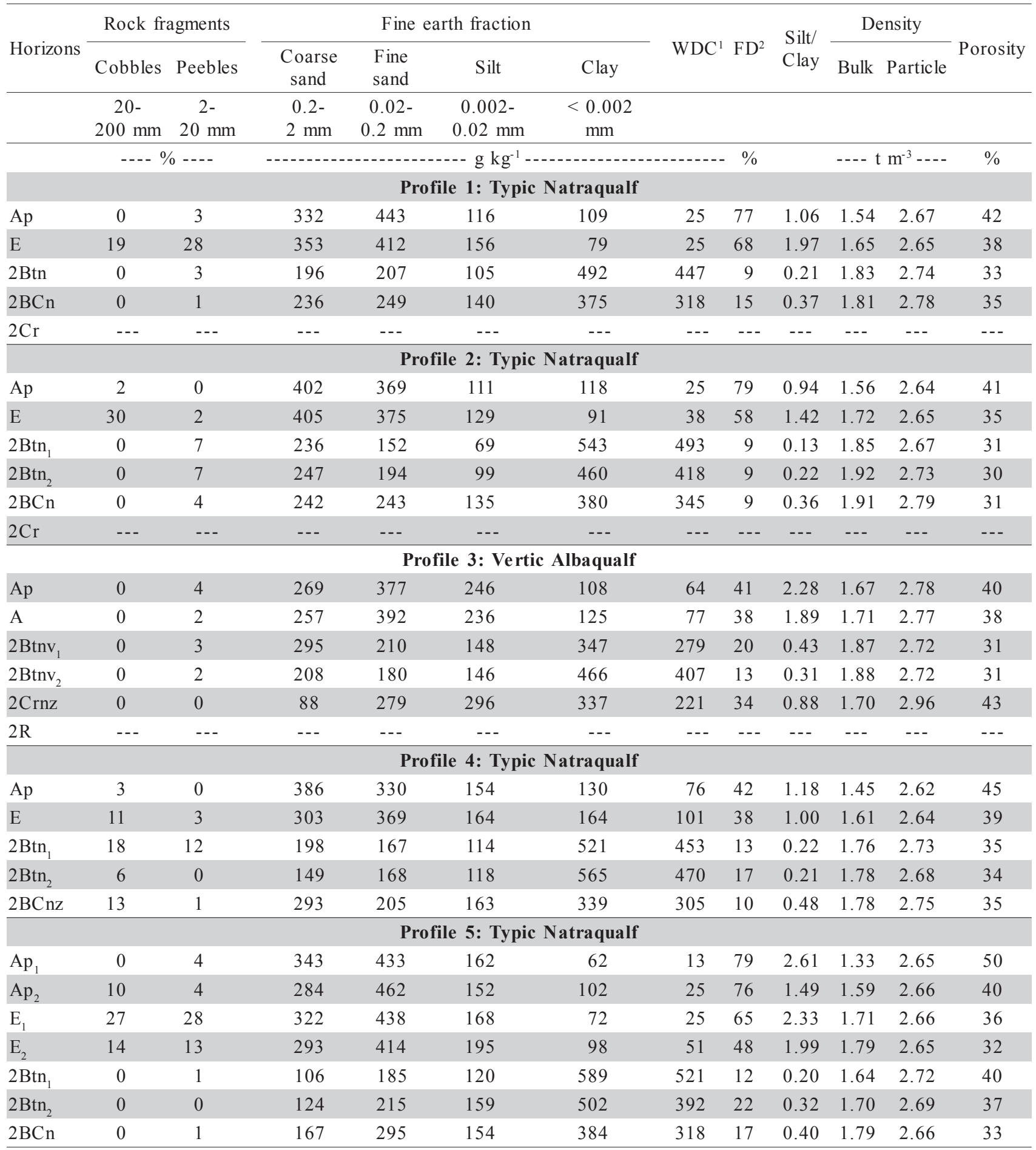

${ }^{1} \mathrm{WDC}=$ water-dispersed clay; ${ }^{2} \mathrm{FD}=$ flocculation degree.

gree, to A horizons. "Cabeça do barro" and "barro de loiça” were similar to each other and also to the B horizons. "Pedra mole" was similar to BC horizons, but the respective centroids were not as close in this particular comparison as in the other ones. The most remarkable differences were obtained when comparing surface-or-elluvial categories (A, E, “terra” and "piçarro") with subsurface-or-illuvial categories (B, BC “cabeça do barro", "barro de loiça” and "pedra mole”). Therefore, the "individuals" under study were divided in two groups (Figure 1) as related to their position in the profile: an upper group formed by surface-andelluvial categories, and a lower one formed by subsurface-and-illuvial categories. 
Table 4 - Chemical attributes of soils that are used as a source of pottery clay by peasant potters in Chã da Pia, Paraíba, Brazil.

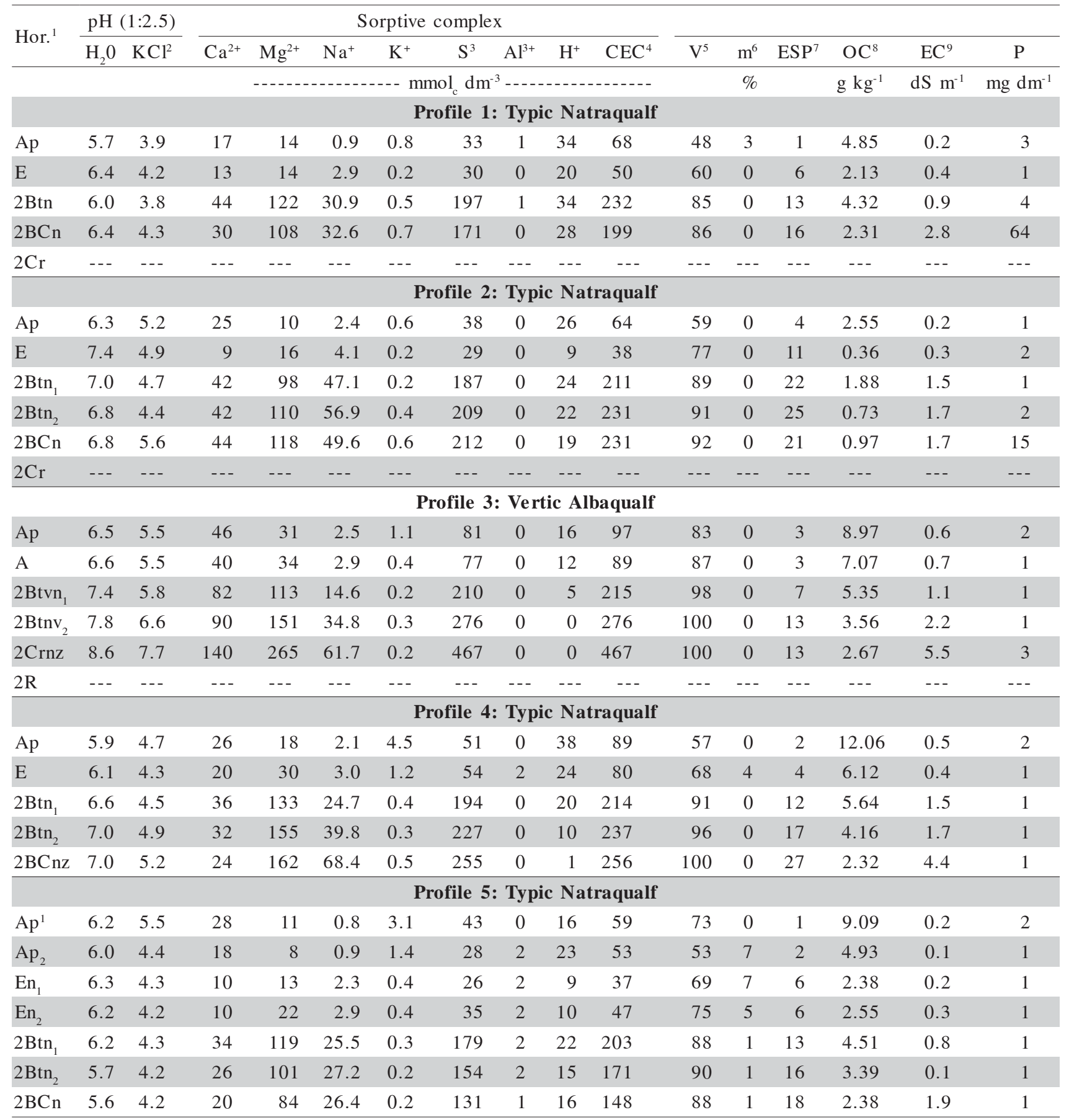

${ }^{1}$ Horizons; ${ }^{2} 1 \mathrm{~mol} \mathrm{~L}-1 \mathrm{KCl} ;{ }^{3} \mathrm{~S}=$ sum of basic cations; ${ }^{4} \mathrm{CEC}=$ cation exchange capacity; ${ }^{5} \mathrm{~V}=$ base saturation; ${ }^{6} \mathrm{~m}=$ exchangeable aluminium percentage; ${ }^{7} \mathrm{ESP}=$ exchangeable sodium percentage; ${ }^{8} \mathrm{OC}=$ organic carbon; ${ }^{9} \mathrm{EC}=$ electrolytic conductivity.

Three canonical roots were significant $(P<0.01)$. Nevertheless, the following discussion is based on the first two roots, disregarding the others (Table 7), since the first canonical root explained most of the variation (68\%), while the second root added $22 \%$ resulting in an accumulated total of $90 \%$. Canonical correlation $\mathrm{R}$ was very high for the first two roots, demonstrating the high degree of correlation between these two roots and the other variables. Averages of each category in the multivariate space that was defined by these two main canonical roots (Figure 1) were useful to indicate those groups that were distinguished by a root. The first root made distinctions between the categories situated in the upper positions of the profile ("terra", "piçarro", A and E) and the lower ones ("cabeça do barro”, "barro de loiça”, "pedra 
mole”, Bt and BC). The second root, on the other hand, enabled a distinction between the categories more influenced by the proximity of the parent material ("pedra mole" and BC) from the others.

Structural coefficients (Table 8) expressed correlations between the variables in the model and the discriminant functions, making it possible to assign meaning to the discriminant functions (roots). In the first root, negative values of the following variables are outstanding: water-dispersed clay, soil texture, total clay, exchangeable magnesium, stickiness, plasticity, depth, and exchangeable sodium. In the second root, positive values obtained for soil depth, electrolytic conductivity, extractable phosphorus and exchangeable sodium were outstanding.

Through the trend revealed in the first root, it was seen that the categories with lower position ("barro de loiça”, “cabeça do barro”, “pedra mole”, Bt and, BC) stood out from the upper ones, the first ones having higher values for the variables previously depicted in table 8 (water-dispersed clay, texture, total clay, exchangeable magnesium, stickiness, plasticity, depth and exchangeable sodium). Similarly, it was demonstrated through the second root that "pedra mole" and BC were similar within themselves and distinguished from the other categories, since they showed higher values for the variables previously cited (depth, electrolytic conductivity, extractable phosphorus and exchangeable sodium).

This comparison between formal and local soil categories made it possible to accept the hypothesis of morphological, physical and chemical similarities between the layers recognized by potter-farmers and the pedogenetical horizons from which these materi-

Table 5 - Variables included and excluded from the model, with respective lambda, F, and $P$ values.

\begin{tabular}{|c|c|c|c|}
\hline Variable & Partial Lambda & $\mathrm{F}(8.17)$ & $\mathrm{P}$ \\
\hline Water-dispersed clay $\left(\mathrm{g} \mathrm{kg}^{-1}\right)$ & 0.57 & 1.59 & 0.20 \\
\hline Depth $(\mathrm{cm})$ & 0.20 & 8.28 & 0.00 \\
\hline Exchangeable $\mathrm{Mg}\left(\mathrm{mmol}_{\mathrm{c}} \mathrm{dm}^{-3}\right)$ & 0.46 & 2.54 & 0.05 \\
\hline Pebbles $(\%)$ & 0.38 & 3.54 & 0.01 \\
\hline Cobbles $(\%)$ & 0.41 & 3.05 & 0.03 \\
\hline Electrolytic conductivity $\left(\mathrm{dS} \mathrm{m}^{-1}\right)$ & 0.38 & 3.47 & 0.01 \\
\hline Fine sand $\left(\mathrm{g} \mathrm{kg}^{-1}\right)$ & 0.40 & 3.17 & 0.02 \\
\hline Texture & 0.46 & 2.49 & 0.05 \\
\hline Silt $\left(\mathrm{g} \mathrm{kg}^{-1}\right)$ & 0.43 & 2.79 & 0.04 \\
\hline Stickiness & 0.58 & 1.51 & 0.23 \\
\hline Exchangeable $\mathrm{Al}\left(\mathrm{mmol}_{\mathrm{c}} \mathrm{dm}^{-3}\right)$ & 0.50 & 2.13 & 0.09 \\
\hline $\mathrm{pH}$ in $\mathrm{H}_{2} \mathrm{O}$ & 0.41 & 3.12 & 0.02 \\
\hline Extractable $\mathrm{P}\left(\mathrm{mg} \mathrm{dm}^{-3}\right)$ & 0.31 & 4.68 & 0.00 \\
\hline $\mathrm{pH}$ in $\mathrm{KCl} 1 \mathrm{~mol} \mathrm{~L}^{-1}$ & 0.32 & 4.49 & 0.00 \\
\hline Hue (from color) & 0.42 & 2.99 & 0.03 \\
\hline Total clay $\left(\mathrm{g} \mathrm{kg}^{-1}\right)$ & 0.62 & 1.33 & 0.29 \\
\hline Particle density $\left(\mathrm{t} \mathrm{m}^{-3}\right)$ & 0.47 & 2.43 & 0.06 \\
\hline Chroma (from color) & 0.35 & 3.87 & 0.01 \\
\hline Plasticity & 0.42 & 2.93 & 0.03 \\
\hline Exchangeable $\mathrm{Ca}\left(\mathrm{mmol}_{\mathrm{c}} \mathrm{dm}^{-3}\right)$ & 0.58 & 1.54 & 0.22 \\
\hline Exchangeable $\mathrm{Na}\left(\mathrm{mmol}_{\mathrm{c}} \mathrm{dm}^{-3}\right)$ & 0.53 & 1.87 & 0.13 \\
\hline Value (from color) & 0.61 & 1.38 & 0.27 \\
\hline${ }^{1}$ Exchangeable $\mathrm{K}\left(\mathrm{mmol}_{\mathrm{c}} \mathrm{dm}^{-3}\right)$ & 0.74 & 0.71 & 0.68 \\
\hline${ }^{1}$ Exchangeable $\mathrm{H}\left(\mathrm{mmol}_{\mathrm{c}} \mathrm{dm}^{-3}\right)$ & 0.74 & 0.70 & 0.69 \\
\hline 'Organic C $\left(\mathrm{g} \mathrm{kg}^{-1}\right)$ & 0.79 & 0.52 & 0.82 \\
\hline${ }^{1}$ Flocculation degree (\%) & 0.74 & 0.70 & 0.69 \\
\hline${ }^{1}$ Bulk density $\left(\mathrm{t} \mathrm{m}^{-3}\right)$ & 0.84 & 03.9 & 0.91 \\
\hline${ }^{1}$ Porosity $(\%)$ & 0.85 & 0.36 & 0.93 \\
\hline
\end{tabular}

${ }^{1}$ variables excluded from the model. 


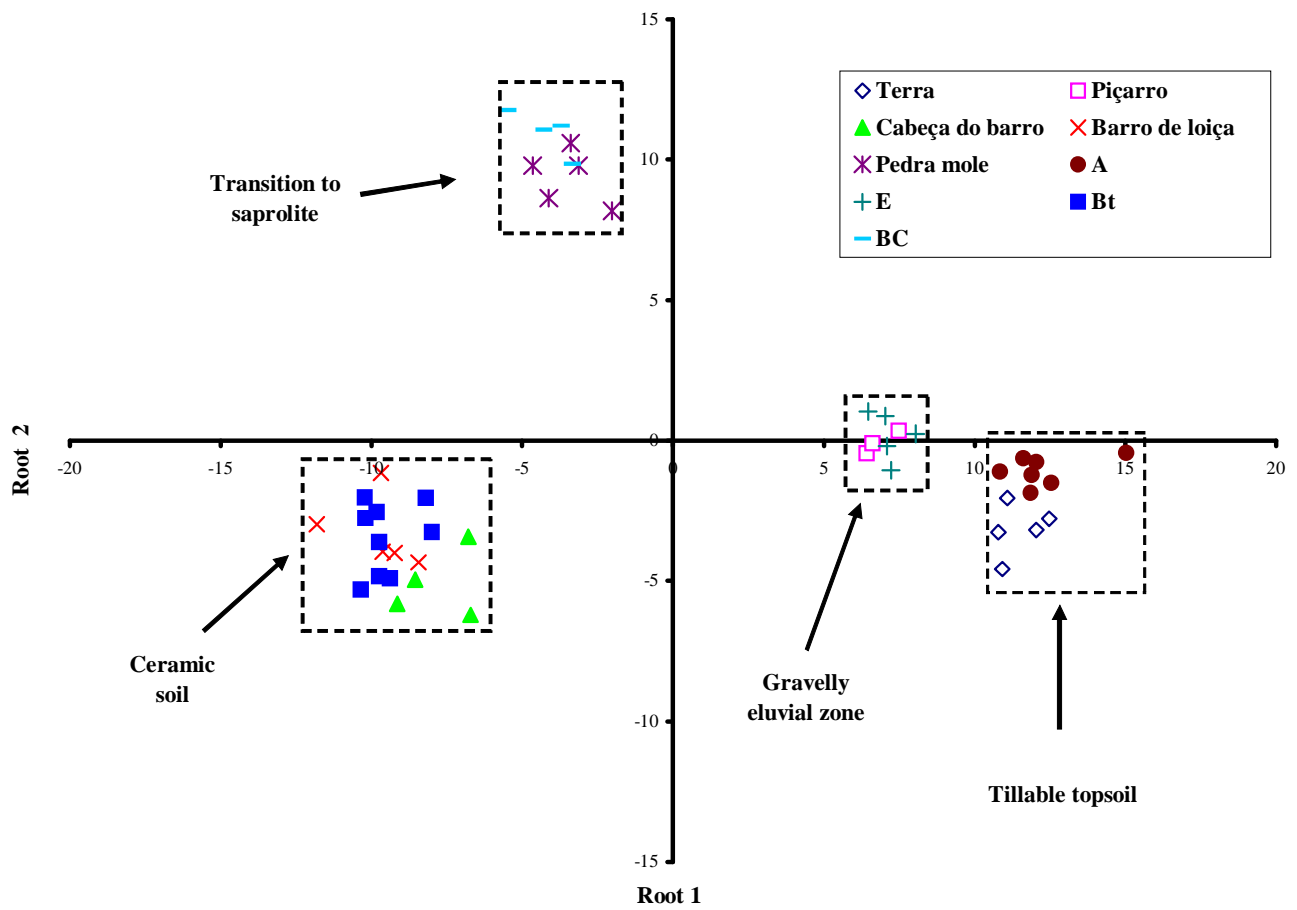

Figure 1 - Graphic representation of canonical roots, showing the distribution of soil horizons (formal categories) and layers (local categories) in a multivariate space. "Terra” (earth), "piçarro" (gravelly bleached soil), "barro de loiça” (pottery clay), "pedra mole” (soft rock), and "cabeça do barro” (clay head) are layers recognized by potter-farmers. A, E, B, BC and C are pedogenetic horizons of the same soils.

Table 6 - Square Mahalanobis distance.

\begin{tabular}{|c|c|c|c|c|c|c|c|c|c|}
\hline & "Terra" & "Piçarro" & A horizon & E horizon & B horizon & $\mathrm{BC}$ horizon & $\begin{array}{l}\text { "Barrode } \\
\text { loiça" }\end{array}$ & $\begin{array}{l}\text { "Pedra } \\
\text { Mole" }\end{array}$ & $\begin{array}{c}\text { "Cabeça do } \\
\text { barro" }\end{array}$ \\
\hline "Terra"1 & 0.00 & --- & --- & --- & --- & --- & --- & --- & --- \\
\hline "Piçarro"2 & 105.03 & 0.00 & --- & --- & --- & --- & --- & --- & --- \\
\hline A horizon & 19.53 & 133.44 & 0.00 & --- & --- & --- & --- & --- & --- \\
\hline E horizon & 90.33 & 49.40 & 126.07 & 0.00 & --- & --- & --- & --- & --- \\
\hline B horizon & 551.43 & 392.93 & 611.63 & 393.31 & 0.00 & --- & --- & --- & --- \\
\hline $\mathrm{BC}$ horizon & 578.02 & 404.55 & 529.48 & 392.16 & 322.95 & 0.00 & --- & --- & --- \\
\hline "Barro de loiça"3 & 563.44 & 413.26 & 614.86 & 426.05 & 8.6769 & 306.43 & 0.00 & --- & --- \\
\hline "Pedra mole"4 & 487.81 & 290.21 & 484.81 & 290.99 & 266.12 & 82.16 & 276.39 & 0.00 & -- \\
\hline "Cabeça do barro"5 & 470.61 & 351.34 & 535.21 & 364.55 & 18.78 & 361.51 & 20.61 & 305.52 & 0.00 \\
\hline
\end{tabular}

${ }^{1}$ earth; ${ }^{2}$ gravelly bleached soil; ${ }^{3}$ pottery clay; ${ }^{4}$ soft rock; ${ }^{5}$ clay head.

Table 7 - Significance indexes for the canonical roots.

\begin{tabular}{lccccc}
\hline Root & Eigen value & Canonical R & Wilk's Lambda & Significance (P) & $\begin{array}{c}\text { Explained variance } \\
\text { (cummulative) }\end{array}$ \\
\hline 1 & 99.26 & 1.00 & 0.00 & 0.00 & 0.68 \\
2 & 32.84 & 0.99 & 0.00 & 0.00 & 0.90 \\
3 & 8.51 & 0.95 & 0.00 & 0.00 & 0.96 \\
4 & 2.85 & 0.86 & 0.03 & 0.22 & 0.98 \\
5 & 1.98 & 0.82 & 0.12 & 0.74 & 0.99 \\
6 & 0.70 & 0.64 & 0.37 & 0.99 & 1.00 \\
7 & 0.36 & 0.52 & 0.62 & 1.00 & 1.00 \\
\hline 8 & 0.18 & 0.39 & 0.85 & 0.99 & 1.00 \\
\hline
\end{tabular}


Table 8 - Indexes of correlation between the variables and the canonical roots.

\begin{tabular}{|c|c|c|}
\hline Variable & Root 1 & Root 2 \\
\hline Water-dispersed clay $\left(\mathrm{g} \mathrm{kg}^{-1}\right)$ & -0.30 & -0.08 \\
\hline Depth $(\mathrm{cm})$ & -0.16 & 0.23 \\
\hline Exchangeable $\mathrm{Mg}\left(\mathrm{cmol}_{\mathrm{c}} \mathrm{dm}^{-3}\right)$ & -0.24 & 0.05 \\
\hline Pebbles $(\%)$ & 0.04 & -0.01 \\
\hline Cobbles $(\%)$ & 0.04 & 0.00 \\
\hline Electrolytic conductivity $\left(\mathrm{dS} \mathrm{m}^{-1}\right)$ & -0.09 & 0.16 \\
\hline Fine sand $\left(\mathrm{g} \mathrm{kg}^{-1}\right)$ & 0.25 & 0.04 \\
\hline Texture & -0.27 & -0.03 \\
\hline Silt $\left(\mathrm{g} \mathrm{kg}^{-1}\right)$ & 0.05 & 0.02 \\
\hline Stickiness & -0.23 & -0.02 \\
\hline Exchangeable $\mathrm{Al}\left(\mathrm{cmol}_{\mathrm{c}} \mathrm{dm}^{-3}\right)$ & 0.01 & -0.01 \\
\hline $\mathrm{pH}$ in $\mathrm{H}_{2} \mathrm{O}$ & -0.04 & 0.02 \\
\hline Extractable $\mathrm{P}\left(\mathrm{mg} \mathrm{dm}^{-3}\right)$ & -0.01 & 0.11 \\
\hline $\mathrm{pH}$ in $\mathrm{KCl}$ & -0.01 & 0.01 \\
\hline Hue & -0.04 & 0.06 \\
\hline Clay $\left(\mathrm{g} \mathrm{kg}^{-1}\right)$ & -0.26 & -0.08 \\
\hline Particle density $\left(\mathrm{t} \mathrm{m}^{-3}\right)$ & -0.05 & 0.08 \\
\hline Chroma & -0.03 & 0.05 \\
\hline Plasticity & -0.20 & -0.02 \\
\hline Exchangeable $\mathrm{Ca}\left(\mathrm{cmol}_{\mathrm{c}} \mathrm{dm}^{-3}\right)$ & -0.05 & -0.03 \\
\hline Exchangeable $\mathrm{Na}\left(\mathrm{cmol}_{\mathrm{c}} \mathrm{dm}^{-3}\right)$ & -0.15 & 0.11 \\
\hline Value (from color) & -0.09 & 0.06 \\
\hline
\end{tabular}

als are normally collected. On the other hand, the evident distinction among categories located in upper and lower positions of the soil profile was coherent with certain characteristics of Albaqualfs and Natraqualfs, such as the high textural gradient and the abrupt transition from horizons A or E to the underlying Bt. The difficulty in distinguishing between "barro de loiça" and "cabeça do barro", through the chosen statistical procedure seemed to be related to field situations, since the potters not always reject the materials from the top of Bt ("cabeça do barro") when they collected the clay for pottery.

Researchers with formal pedological training might also have doubts and divergences, on the field, related to a possible subdivision of the Bt horizon in sub-horizons, when studying Albaqualfs and Natraqualfs, and might depend on laboratory analysis and further evaluations to define the horizons or subhorizons to be accepted in each case. Sometimes it was possible to visualize a strong darkness in the external face of the aggregates, on the top of $\mathrm{Bt}$ ("cabeça do barro"), but the structure could be formed by blocks or prisms comprehending all of this horizon extension, making a subdivision unfeasible.
Williams \& Ortiz-Solorio (1981) obtained a low degree of correspondence between soil categories recognized by farmers and researchers, mainly because in that situation, the local classification was based on the features of a bi-dimensional taxonomic unit (tillable topsoil), rather than a three-dimensional one (soil profile). Nevertheless, their data demonstrated that local categories reflected discontinuities on the soil surface, which originated measurable and statistically valid categories. Queiroz \& Norton (1992) demonstrated that the cluster arrangement of soils from the Acaraú Valley (Ceará State), based on morphological data from formal soil surveys, was strongly coincident with the soil categories indicated by peasants, although there were many differences in nomenclature between the two data sets. Further analysis demonstrated that these clusters differed among themselves in relation to water holding capacity and $\mathrm{pH}$. As a consequence, the local classification was considered to be valid for distinguishing soils as related to non-morphological characteristics as well. For each soil profile, Queiroz \& Norton (1992) inserted morphological data of two horizons (a surface and a subsurface one), so that the "individuals" that they submitted to the clustering test were "soils", each of them represented by a pair of horizons.

The practical applications and epistemological implications of statistically analyzing data from local categories of soils, attempting to validate local knowledge through laboratorial analysis, have been submitted to divergent interpretations and criticism. Thus, Winkler-Prins (1999) evaluated the quest of a "scientific rationale" underlying local soil knowledge. Her understanding is that these studies aiming at validating local knowledge through formal procedures have the merit of clearly demonstrating that this knowledge can be "scientifically valid" and that consulting with local people is a beneficial activity for development practitioners. On the other hand, she emphasized that some validation attempts could presume "that scientific knowledge is superior to local knowledge, and that the later needs to be proven in order to be used by scientists". This would be contradictory with the idea that local knowledge has its intrinsic value.

Considering these restrictions, statistical and laboratorial studies not only pursue the validation of local knowledge, but also represent opportunities for the emergence of an integrating language, attempting to reduce the distance separating local knowledge from that one practiced and accepted in the academy. These studies may, within certain contexts, revalidate and feedback on the knowledge and practices of people conducting formal scientific research, reconnecting them with the peasant's experience. 


\section{ACKNOWLEDGMENTS}

To the peasant potters who shared their knowledge with the authors. To WWF-Brazil/USAID, for having funded this research. To CAPES/MEC and $\mathrm{CNPq} / \mathrm{MCT}$ for the grants awarded to the first and fourth authors of this paper, respectively. To Professors Rinaldo Luiz Caraciolo Ferreira, and Luciano da Silva Souza, for having provided support and encouragement in various phases of this research.

\section{REFERENCES}

ALBUQUERQUE, U.P.; LUCENA, R.F.P. Métodos e técnicas na pesquisa etnobotânica. Recife: Livro Rápido/NUPPEA, 2004, 189p.

ALVES, A.G.C. Do “barro de loiça” à "loiça de barro": caracterização etnopedológica de um artesanato camponês no Agreste Paraibano. São Carlos: UFSCar, 2004, 163p. (Doctoral Thesis). Available at: http://www.ufscar.br. Accessed on: 3 abr. 2006.

ALVES, A.G.C.; MARQUES, J.G.W. Etnopedologia: uma nova disciplina? Tópicos em Ciência do Solo, v.4, p.321-344, 2005.

ALVES, A.G.C.; MARQUES, J.G.W.; SILVA, I.F.; QUEIROZ, S.B.; RIBEIRO, M.R. Caracterização etnopedológica de Planossolos utilizados em cerâmica artesanal no Agreste Paraibano. Revista Brasileira de Ciência do Solo, v.9, p.379-388, 2005.

ALVES, A.G.C.; RIBEIRO, M.R.; ANJOS, L.H.C.; CORREIA, J.R. Por que estudar os nomes dados aos solos pelos camponeses? Boletim Informativo da Sociedade Brasileira de Ciência do Solo, v.31, p.12-17, 2006.

BARRERA-BASSOLS, N.; ZINCK, J. A. "Land moves and behaves": indigenous discourse on sustainable land management in Pichátaro, Pátzcuaro basin, Mexico. Geografiska Annaler, v.85A, p.229-245, 2003.

BRADY, N.C. Natureza e propriedades dos solos. 7.ed. Rio de Janeiro: Freitas Bastos, 1989. 878p.

CIPRA, J.E.; BIDWELL, O.W.; ROHLF, F.J. Numerical taxonomy os soils from nine orders by cluster analysis. Soil Science Society of America Proceedings, v.34, p.281-287, 1970.

COOPER, M.; TERAMOTO, E.R.; VIDAL-TORRADO, P.; SPAROVEK, G. Learning soil classification with the Kayapó Indians. Scientia Agricola, v.62, p.604-606, 2005.

EMPRESA BRASILEIRA DE PESQUISA AGROPECUÁRIA. Centro Nacional de Pesquisa de Solos. Manual de métodos de análises de solos. 2.ed. Rio de Janeiro: EMBRAPA, CNPS, 1997. 212p.

EMPRESA BRASILEIRA DE PESQUISA AGROPECUÁRIA. Centro Nacional de Pesquisa de Solos. Sistema Brasileiro de Classificação de Solos. 2.ed. Rio de Janeiro: Embrapa Solos, 2006. 306p.

FAIVRE, P. Sols a profil differencié planosoliques à horizon Bt noir de Colombie. Science du Sol, n.2, p.95-110, 1977.

JACOMINE, P.K.T.; RIBEIRO, M.R.; MONTENEGRO, J.O.; SILVA, A.P.; MELO FILHO, H.F.R. Levantamento exploratórioreconhecimento de solos do Estado da Paraíba. Rio de Janeiro: Ministério da Agricultura, Superintendência de Desenvolvimento do Nordeste, 1972. 650p. (Boletim Técnico, 15; Série Pedologia, 8).
KRASILNIKOV, P.V.; TABOR, J.A. Perspectives on utilitarian ethnopedology. Geoderma, v.111, p.197-215, 2003.

NIKIFOROFF, C.C. The history of A, B, C. American Soil Survey Association Bulletin, v.12, p.67-70, 1931.

QUEIROZ, J.S. The Acaraú Valley in Northeast Brazil: vegetation, soils and land-use. Logan: Utah State University, 1985. 201p. (Doctoral Thesis).

QUEIROZ, J.S.; NORTON, B.E. An assessment of an indigenous soil classification used in the caatinga region of Ceará State, Northeast Brazil. Agricultural Systems, v.39, p.289-305, 1992.

QUIROGA, A.R.; BUSCHIAZZO, D.E.; PEINEMANN, N. Management discriminant properties in semiarid soils. Soil Science, v.163, p.591-597, 1998.

SAMPAIO, J.B.M.; MELO, V.; OLIVEIRA, C.A.; FREIRE, L.C.M. Levantamento semidetalhado da área do Planosol Solódico no estado do Rio Grande do Norte. Recife: SUDENE, 1976. 98p.

SANTOS, B.S. Um discurso sobre as ciências. 4.ed. São Paulo: Cortez, 2006, 92p.

SANTOS, R.D.; LEMOS, R.C.; SANTOS, H.G.; KER, J.C.; ANJOS, L.H.C. Manual de descrição e coleta de solo no campo. 5.ed. Viçosa: Sociedade Brasileira de Ciência do Solo, 2005. 92p.

SILVA, A.P.; IMHOFF, S.; GIAROLA, N.F.B.; TORMENA, C.A. Análisis multivariado y univariado en la discriminación de sistemas de uso de suelos del centro de Santa Fe. Edafología, v.8, p.21-34, 2001.

SOIL SURVEY STAFF. Department of Agriculture. Natural resources conservation service. Soil taxonomy: a basic system of soil classification for making and interpreting soil surveys. 2.ed. Washington: USDA, 1999. 870p. (Agricultural Handbook, 436).

SPRADLEY, J.P. The ethnographic interview. Fort Worth: Harcourt Brace Jovanovich, 1979. 247p.

STATSOFT. Statistica for Windows (computer program manual). Tulsa: 1995.

TOLEDO, V.M. Indigenous knowledge of soils: an ethnoecological conceptualization. In: BARRERA-BASSOLS, N.B.; ZINCK J.A. (Ed.). Ethnopedology in a worldwide perspective. Enschede: International Institute for Aerospace and Earth Sciences (ITC), 2000. p.1-9.

VASELLI, O.; BUCCIANTI, A.; DE SIENA, C.; BINI, C.; CORADOSSI, N.; ANGELONE, M. Geochemical characterization of ophioloitic soils in a temperate climate: a multivariate statistical approach. Geoderma, v.75, p.117-133, 1997.

WILLIAMS, B.J.; ORTIZ-SOLORIO, C.A. Middle American folk soil taxonomy. Annals of the American Association of Geographers, v.71, p.335-358, 1981.

WINKLER-PRINS, A.M.G.A. Local soil knowledge: a tool for sustainable land management. Society and Natural Resources, v.12, p.151-161, 1999.

Received August 30, 2006

Accepted June 22, 2007 